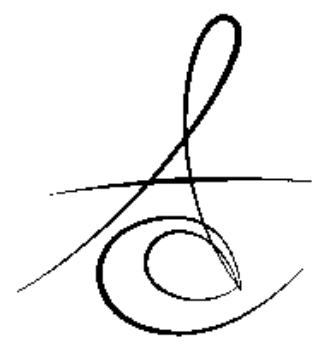

\section{INFLUENCE OF DIFFERENT FINAL ROOT CANAL IRRIGATION REGIMENS ON THE PUSH-OUT BOND STRENGTH OF AH PLUS}

\section{SON YIKAMADA KULLANILAN FARKLI KÖK KANAL SOLÜSYONLARININ AH PLUS PAT İN İN BAĞLANMA DAYANIMI ÜZERİNE ETKİLERİNİN İNCELENMESİ}

Dr. Dt. Emel UZUNOĞLU*
Yrd. Doç. Dr. Sevinç AKTEMUR TÜRKER**

Makale Kodu/Article code: 2163

Makale Gönderilme tarihi: 27.02.2015

Kabul Tarihi: 02.06.2015

\section{ABSTRACT}

Aim: To evaluate influence of different final irrigation regimens on bond-strength of epoxy resin based sealer (AH Plus).

Material and method: Forty-eight mandibular incisors were irrigated with $2.5 \%$ sodium hypochlorite during and after completion of root canal preparation. Roots were divided into 4 groups $(n=12$ ) according to the final irrigation regimens: Group 1: $5 \mathrm{~mL} 17 \%$ ethylenediaminetetraacetic acid (EDTA); Group 2: 5 $\mathrm{mL} 17 \%$ EDTA followed by $5 \mathrm{~mL} 2 \%$ chlorhexidine gluconate (CHX); Group 3: $5 \mathrm{~mL}$ QMix; and Group 4: 5 $\mathrm{mL}$ distilled water as control. All specimens were filled with gutta-percha (GP) and AH Plus. One-millimeter thick four horizontal sections from each root were sliced for bond-strength measurement. Data were statistically analyzed by one-way Anova and Bonferroni tests $(p<0.05)$.

Results: Specimens that were irrigated with EDTA/CHX displayed significantly the highest mean bond strength value $(p<0.001)$. Specimens mainly showed a cohesive failure pattern, regardless of final irrigation regime.

Conclusion: Using $2 \% \mathrm{CHX}$ in the final irrigation after $17 \%$ EDTA was improved AH Plus's bond-strength. Final irrigation with EDTA followed by $\mathrm{CHX}$ was more effective at improving bond strength of $\mathrm{AH}$ Plus compared to QMix that consists EDTA and CHX.

Key Words: adhesion, push-out bond strength, root canal irrigation, root canal sealer

\section{Dr. Sevilay KARAHAN ${ }^{* * *}$}

\section{ÖZET}

Amaç: Son yıkamada kullanılan farklı kök kanal irrigasyon solüsyonlarının epoksi rezin esaslı kök kanal dolgu patının (AH Plus), kök kanal dentinine bağlanma dayanımı üzerindeki etkilerini incelemektir.

Materyal Metod: Kırk sekiz adet tek kanallı, alt çene, ön ve yan keser diş kullanılmıştır. Şekillendirme sırasında örnekler \%2,5'luk sodyum hipoklorit ile irrige edilmiş, şekillendirme bitiminde son yıkama solüsyonuna göre örnekler rastgele 4 gruba ayrılmıştır ( $n=12$ ): Grup 1: $5 \mathrm{ml} \% 17$ etilendiamintetraasetik asit (EDTA); Grup 2: $5 \mathrm{ml} \% 17$ EDTA ardından $5 \mathrm{ml}$ \%2 klorheksidin glukonat (CHX), Grup 3: 5 ml QMix; ve Grup 4: kontrol grubu olarak $5 \mathrm{ml}$ distile su. Tüm örnekler güta-perka ve $\mathrm{AH}$ Plus ile doldurulmuştur. Bağlanma dayanımı testi için her örnekten $1 \mathrm{~mm}$ kalınlığında dörder kesit elde edilmiştir. Bağlanma dayanımı verileri tek yönlü Anova ve Bonferroni testleri ile analiz edilmiştir ( $p<0,05)$.

Bulgular: EDTA/CHX ile irrige edilen örneklerde bağlanma dayanımı değerleri istatistiksel olarak daha yüksek bulunmuştur $(p<0,001)$. Son yıkama solüsyonlarından bağımsız olarak örneklerin çoğunda koheziv başarısızlık gözlenmiştir.

Sonuçlar: Son yıkamada \%17 EDTA'yı takiben \%2 CHX kullanımı AH Plus'ın bağlanma dayanımı değerlerini arttırmıştır. Son yıkamada EDTA ve CHX ayrı ayrı uygulamak AH Plus'ın bağlanma dayanımını, içeriğinde EDTA ve CHX barındıran QMix'e göre daha olumlu etkilemiştir.

Anahtar Kelimeler: adezyon, itme-bağlanma dayanımı, kök kanal irrigasyonu, kök kanal patı

\footnotetext{
* Hacettepe University Faculty of Dentistry Department of Endodontics

** Bülent Ecevit University Faculty of Dentistry Department of Endodontics

*** Hacettepe University Faculty of Medicine Department of Biostatistics
} 


\section{INTRODUCTION}

The use of gutta-percha with a root canal sealer is considered as standard procedure in root canal filling. ${ }^{1,2}$ Root canal sealer should present adequate flow for filling gaps between gutta-percha cones and the canal walls and bond strength to root dentin for contributing to the obturation of the root canal system, because gutta-percha has no adhesion to the canal walls. ${ }^{1-4}$ Different types of sealers have been introduced to the dental market constantly to develop new products having better adhesive properties than the commonly used sealers. ${ }^{3,5}$

Certain important factors may interfere with the sealer adhesion, such as the root canal preparation and cleaning, the filling technique, and the type of sealer. ${ }^{6}$ There are many studies regarding the effect of different final irrigation regimens on the bond strength of sealers. According to the results of the studies, authors claim that final irrigating protocols impact the adhesion of sealers to root dentin. ${ }^{7-10}$

AH Plus (Dentsply, Konstantz, Germany) is one of the commonly used epoxy-resin-based sealer, which has excellent sealing properties and considered as a gold standard against which all new sealers must be compared. ${ }^{2,4}$

This study was designed to examine the effect of final irrigant regimens (17\% EDTA, 17\% EDTA/2\% $\mathrm{CHX}$, QMix, Distilled water as control) on the push-out bond strength of $\mathrm{AH}$ Plus to root dentine. The null hypothesis tested was these regimens had no influence on the sealer-dentine bond strength of $\mathrm{AH}$ Plus.

\section{MATERIALS AND METHODS}

Forty-eight extracted human mandibular incisors were radiographed to select only those with single root, single canal and a similar radicular morphology. Teeth with caries, cracks and immature apices were excluded. The selected teeth were decoronated $12 \mathrm{~mm}$ from the anatomic apex. Working length was established using a size $10 \mathrm{~K}$-file (Mani Inc, Tochigi, Japan) to the root canal terminus and subtracting $0.5 \mathrm{~mm}$ from this measurement. The root canals were prepared using ProTaper rotary instruments (Dentsply Maillefer, Ballaigues, Stwizerland) up to F3. Warm wax (Modelling Wax;
Dentsply DeTrey, Weybridge, UK) was used to seal the apical foramen. After each instrument, $3 \mathrm{~mL}$ of $2.5 \%$ sodium hypochlorite $(\mathrm{NaOCl})$ was used for irrigation. After instrumentation was completed all specimens were irrigated with $5 \mathrm{~mL}$ of $2.5 \% \mathrm{NaOCl}$. After the instrumentation and drying of the root canals with absorbent paper points, the roots were assigned to four groups $(n=12)$ according to the final rinse protocol: Group 1: $5 \mathrm{~mL}$ of 17\% EDTA (Biodinâmica, Ibiporã, Brazil), maintained in the root canal for $1 \mathrm{~min}$; Group 2: $5 \mathrm{~mL}$ of $17 \%$ EDTA, maintained in the root canal for $1 \mathrm{~min}$ and $5 \mathrm{~mL}$ of $2 \%$ chlorhexidine gluconate ( $\mathrm{CHX}$, Drogsan Medicine, Ankara, Turkey) maintained in the root canal for $1 \mathrm{~min}$; Group 3: $5 \mathrm{~mL}$ QMix (Dentsply Tulsa Dental Specialties, Tulsa, OK, USA), maintained in the root canal for $1 \mathrm{~min}$ and Group 4: $5 \mathrm{~mL}$ distilled water (control group).

All the root canals were dried with paper points. Then the root canals were filled using AH Plus (Dentsply, Konstantz, Germany) sealer and a F3 guttapercha point (Dentsply Maillefer, Ballaigues, Switzerland) using single cone technique. After canal obturation, roots were radiographed to make sure the canals were fully obturated. After root filling, the coronal $1 \mathrm{~mm}$ of the filling materials was removed from each specimen, and the space in each was filled with a temporary filling material (Cavit; 3M ESPE, Seefeld, Germany). Subsequently, all specimens were stored at $37{ }^{\circ} \mathrm{C}$ in $100 \%$ humidity for 2 weeks to allow the sealers to fully set and then the roots were embedded into acrylic resin blocks.

Before push-out testing, each root was horizontally sectioned into 1 -mm-thick slices with a water-cooled precision saw (Isomet; Buehler, Lake Bluff, IL). Four slices were obtained from each root from the coronal-to-apical direction. Sections were eliminated from the study in the case of any voids in the root filling or if they had a non-circular shape. Three different-sized plungers $(0.6,0.7$ and $0.8 \mathrm{~mm})$ were used to closely match the size of the filling material. The plungers were connected to the load cell of a universal testing machine (Lloyd; Fareham, Hants, England). A vertical load was applied in an apical to coronal direction at a rate of $1.0 \mathrm{~mm} / \mathrm{min}$ on the root canal filling. Failure was determined when the graph showed a reduction in load. The maximum failure load was recorded in Newtons and was used to calculate the push-out bond strength in megapascals (MPa) 
according to the following formula ${ }^{11}$ :

Maximum load $(\mathrm{N})$

Push-out bond strength $(\mathrm{MPa})=$

Adhesion area of root canal filling $\left(\mathrm{mm}^{2}\right)$

The adhesion area of each section was calculated as: $\left(\pi r_{1}+\pi r_{2}\right) L$, where $L=\sqrt{ }\left(r_{1}-r_{2}\right)^{2}+h^{2}, \pi$ is the constant $3.14, r_{1}$ is the smaller radius, $r_{2}$ is the larger radius, and $\mathrm{h}$ is the thickness of the slice in $\mathrm{mm}$.

The data were analyzed using one-way ANOVA and the post hoc Bonferroni test. Statistically significant differences among the groups were set at $p$ $<0.05$. After the push-out bond strength test, the failure modes were analyzed by examining each debonded specimen under a stereomicroscope (Olympus Corporation, Taichung, Taiwan) at 40x magnification. The failures were classified according to Huffman et al. ${ }^{12}$ : adhesive failure: along the sealerdentine interface; cohesive: within the sealer; or mixed failures: that consisted of partial adhesive failure along the dentinal walls and partial cohesive failure within the sealer.

\section{RESULTS}

The mean values of bond strengths recorded for experimental groups and control group are presented in Table 1. There was a significant difference between groups $(p<0.05)$. Specimens irrigated with EDTA/CHX (2.82 \pm 0.52) displayed significantly higher bond strengths values compared to EDTA, QMix and distilled water $(p<0.001$, for all comparisons). The modes of fracture are displayed in Figure 1. Cohesive failure was the most frequent type of failure in all groups.

Table 1: The mean values of push out bond strength (MPa) and standard deviation of experimental groups.

\begin{tabular}{|l|l|l|}
\hline Groups & Final irrigation regimen & Mean \pm Std Dev. \\
\hline 1 & EDTA & $1.65 \pm 1.16^{\mathrm{a}}$ \\
\hline 2 & EDTA/CHX & $2.82 \pm 0.52^{\mathrm{b}}$ \\
\hline 3 & QMix & $1.34 \pm 0.78^{\mathrm{a}}$ \\
\hline 4 & $\begin{array}{l}\text { Distilled Water (control } \\
\text { group }\end{array}$ & $1.56 \pm 0.82^{\mathrm{a}}$ \\
\hline
\end{tabular}

*Different superscript letters indicate statistically significant differences between groups $(p<0.05)$.

\section{DISCUSSION}

In the present study EDTA/CHX combination favored the push out bond strength values of $\mathrm{AH}$ Plus sealer to root canal dentine as previously reported Hashem et al. ${ }^{13}$ Lottani et al. ${ }^{14}$ reported that the type of calcium chelating agent has a significant impact on the root dentine wall, EDTA will cause a complete demineralization of the exposed wall, whilst organic acids cause a mineral gradient. Previous studies reported higher bond strength values for $\mathrm{AH}$ Plus to dentin treated with chelates after $\mathrm{NaOCl}$ irrigation. ${ }^{8,10,15,16}$

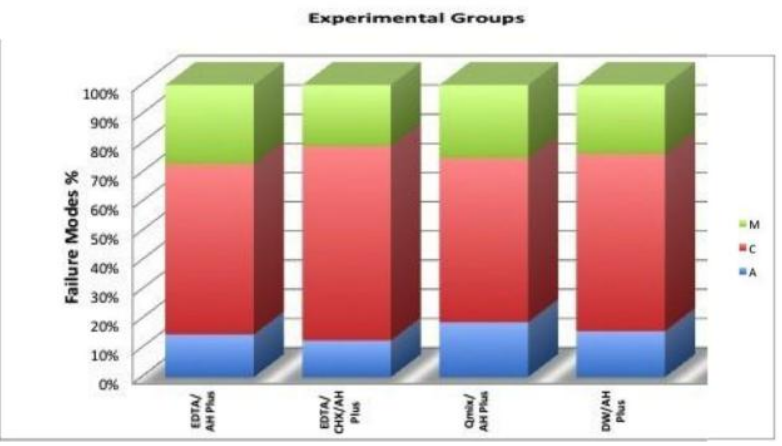

Figure 1: Failure pattern distribution of experimental groups tested (Adhesive failure $(A)$ : along the sealer-dentine inter face; Cohesive (C): within the sealer; or Mixed failures (M): that consisted of partial adhesive failure along the dentinal walls and partial cohesive failure within the sealer. DW: Distilled Water)

$\mathrm{CHX}$ has been suggested as an alternative irrigating solution that could replace $\mathrm{NaOCl}$, especially in cases of open apex or allergy, because of its biocompatibility. ${ }^{17,18}$ Furthermore, it has been speculated that $\mathrm{CHX}$ could have a positive effect on dentine bonding because of its inhibitory effect on matrix metalloproteinases. ${ }^{19}$ Flushing the root canal with $2 \% \mathrm{CHX}$ after $17 \%$ EDTA enhanced the bond strength due to the presence of surface surfactant in $\mathrm{CHX}$ composition that increases the dentine permeability as mentioned before. ${ }^{9,13}$

QMix is a new irrigating solution that contains EDTA, $2 \% \mathrm{CHX}$, and a detergent, and its $\mathrm{pH}$ is slightly above neutral. It removes smear layer as effectively as $17 \%$ EDTA $^{20}$ and favors the wetting of root canal dentine by $\mathrm{AH}$ Plus. ${ }^{7}$ The presence of surfactants in

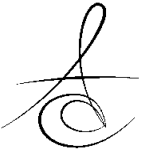


QMix did not increase the bond strength of $\mathrm{AH}$ Plus in relation to $17 \%$ EDTA consistent with previous study. ${ }^{21}$ The rationale of adding a surface-active agent in QMix is because of its ability to lower surface tension of solutions and increase their wettability. ${ }^{22}$ On the other hand, it is reported that the combination of surfactants does not alter the properties of EDTAbased formulations. ${ }^{23}$ Ballal et al. ${ }^{7}$ displayed that wettability or spreading of $\mathrm{AH}$ Plus on root canal dentine was reduced when only EDTA was used as the final irrigant compared to QMix and authors attributed this result to the presence of surface surfactant in $\mathrm{CHX}$ composition, which increases the dentin surface energy and, hence, its wettability, a property that is required for the adhesion of sealer. Also in the present study, mean bond strength values of specimens irrigated with EDTA/CHX were significantly higher than EDTA alone. However, there was no difference between EDTA alone and QMix regarding the bond strengths, so the higher bond strength values could not be attributed to only $\mathrm{CHX}$ existence.

The materials tested were prepared and applied according to the manufacturer's instructions, in the current study. Thus, $\mathrm{AH}$ Plus was used with gutta-percha cones. However, when testing the pushout bond strength, failure could occur at the guttapercha/sealer interface. Clinically, however, filling with mere AH Plus is not advisable, because the material sets to a hard consistency and thus makes retreatment almost impossible. ${ }^{15}$ There is a correlation between the failure modes and bond strength of the AH Plus. The amount of cohesive failures could explain the highest adhesion to dentine. This is in agreement with the findings of Prado et al. ${ }^{9}$ who reported a cohesive failure pattern in the AH Plus sealer group.

\section{CONCLUSION}

Within the limitation of this study, the null hypothesis was rejected. EDTA/CHX combination improved $\mathrm{AH}$ Plus bond strength to dentine compared to EDTA alone and QMix.

Acknowledgement: The authors deny any conflict of interest.

\section{REFERENCES}

1. Guinesi AS, Faria G, Tanomaru-Filho M, BonettiFilho I. Influence of sealer placement technique on the quality of root canal filling by lateral compaction or single cone. Braz Dent J 2014;25:117-22.

2. Nagas E, Cehreli Z, Uyanik MO, Durmaz V. Bond strength of a calcium silicate-based sealer tested in bulk or with different main core materials. Braz Oral Res 2014;28. pii: S1806-83242014000100256.

3. Faria-Júnior NB, Tanomaru-Filho $\mathrm{M}$, Berbert $\mathrm{FL}$, Guerreiro-Tanomaru JM. Antibiofilm activity, pH and solubility of endodontic sealers. Int Endod J 2013;46:755-62.

4. Marciano MA, Guimaraes BM, Ordinola-Zapata R, Bramante CM, Cavenago BC, Garcia RB, Bernardineli N, Andrade FB, Moraes IG, Duarte MA. Physical properties and interfacial adaptation of three epoxy resin-based sealers. J Endod 2011;37:1417-21.

5. Schwartz R. Adhesive density and endodontics: part 2-bonding in the root canal system: the promise and the problems-a review. J Endod 2006;32:125-34.

6. Ricucci D, Lin LM, Spangberg LS. Wound healing of apical tissues after root canal therapy: A long-term clinical, radiographic, and histopathologic observation study. Oral Surg, Oral Med, Oral Pathol, Oral Radiol, Endod 2009;108:609-21.

7. Ballal NV, Tweeny A, Khechen K, Prabhu KN, Satyanarayan, Tay FR. Wettability of root canal sealers on intraradicular dentine treated with different irrigating solutions. J Dent 2013;41:55660.

8. Nunes VH, Silva RG, Alfredo E, Sousa-Neto MD, Silva-Sousa YT. Adhesion of Epiphany and AH Plus sealers to human root dentin treated with different solutions. Braz Dent J 2008;19:46-50.

9. Prado M, Simao RA, Gomes BP. Effect of different irrigation protocols on resin sealer bond strength to dentin. J Endod 2013;39:689-92.

10. Vilanova WV, Carvalho Junior JR, Alfredo E, SousaNeto MD, Silva-Sousa YT. Effect of intracanal irrigants on the bond strength of epoxy resinbased and methacrylate resin-based sealers to root canal walls. Int Endod J 2012;45:42-8. 
11. Nagas E, Cehreli ZC, Durmaz V, Vallittu PK, Lassila LV. Regional push-out bond strength and coronal microleakage of Resilon after different light-curing methods. J Endod 2007;33:1464-8.

12. Huffman BP, Mai S, Pinna L, Weller RN, Primus CM, Gutmann JL, Pashley DH, Tay FR. Dislocation resistance of ProRoot Endo Sealer, a calcium silicate-based root canal sealer, from radicular dentine. Int Endod J 2009;42:34-46.

13. Hashem AA, Ghoneim AG, Lutfy RA, Fouda MY. The effect of different irrigating solutions on bond strength of two root canal-filling systems. J Endod 2009;35:537-40.

14. Lottanti S, Gautschi H, Sener B, Zehnder M. Effects of ethylenediaminetetraacetic, etidronic and peracetic acid irrigation on human root dentine and the smear layer. Int Endod J 2009;42:335-43.

15. Neelakantan $P$, Subbarao C, Subbarao CV, DeDeus $G$, Zehnder $M$. The impact of root dentine conditioning on sealing ability and push-out bond strength of an epoxy resin root canal sealer. Int Endod J 2011;44:491-8.

16. Çiçek E, Özerol NB. İki Farklı Kanal Patının Farklı İrrigasyon Solüsyonları Kullanılarak Push-Out Yöntemi İle Dentine Bağlanma Dirençlerinin Değerlendirilmesi. Atatürk Üniv Diş Hek Fak Derg 2014;24:16-21.

17. Ferraz CC, Gomes BP, Zaia AA, Teixeira FB, SouzaFilho FJ. Comparative study of the antimicrobial efficacy of chlorhexidine gel, chlorhexidine solution and sodium hypochlorite as endodontic irrigants. Braz Dent J 2007;18:294-8.

18. Gomes BP, Martinho FC, Vianna ME. Comparison of $2.5 \%$ sodium hypochlorite and $2 \%$ chlorhexidine gel on oral bacterial lipopolysaccharide reduction from primarily infected root canals. J Endod 2009;35:1350-3.

19. Hebling J, Pashley DH, Tjaderhane L, Tay FR. Chlorhexidine arrests subclinical degradation of dentin hybrid layers in vivo. J Dent Res 2005;84:741-6.

20. Dai L, Khechen K, Khan S, Gillen B, Loushine BA, Wimmer CE, Gutmann JL, Pashley D, Tay FR. The effect of QMix, an experimental antibacterial root canal irrigant, on removal of canal wall smear layer and debris. J Endod 2011;7:80-4.
21. Aranda-Garcia AJ, Kuga MC, Vitorino KR, ChávezAndrade GM, Duarte MA, Bonetti-Filho I, Faria G, Só MV. Effect of the root canal final rinse protocols on the debris and smear layer removal and on the push-out strength of an epoxy-based sealer. Microsc Res Tech 2013;76:533-7.

22. Giardino L, Ambu E, Becce C, Rimondini L, Morra M. Surface tension comparison of four common root canal irrigants and two new irrigants containing antibiotic. J Endod 2006;32:1091-3.

23. Cruz-Filho AM, Sousa-Neto MD, Saquy PC, Pecora JD. Evaluation of the effect of EDTAC, CDTA, and EGTA on radicular dentin microhardness. J Endod 2001;27:183-4.

\section{Yazışma Adresi:}

Emel Uzunoglu, DDS, PhD

Department of Endodontics, Faculty of Dentistry, Hacettepe University Sıhhiye, Ankara/Turkey, 06100.

Phone: +903123052260

Fax: +903123104440

E-mail address: emel_dt@hotmail.com 